"On the Original Form of Sedimentary Deposits": Brit. Assoc. Rep. (1902), pp. 603-604; GEoL. YAG. (1903), pp. 12-18 and 72-80.

"Notes on the species 'Am. plicatilis' and 'Am. biplex' of Sowerby": Geor. Mag. (1901), pp. 16:-166.

"The Silurian Cephalopoda": Geol. Assoc. Proc., vol. xviii (1904), pp. 451-454.

"On the Order of Succession of the Manx Slates in their Northern Half, and its bearing on the Origin of the Schistose Breccia associated therewith": Quart. Journ. Geol. Soe., vol. lxi (1905); pp. 358-373.

\title{
Articles.
}

"Cuttleftsh": Fncyclopedia Britannica.

"Geulogy of Nottinghamshire" : Victoria History of tho Countios.

"Urigin and IIistory of the Thames": Marylebone Mercury (1891).

\section{GEORGE FREDERICK HARRIS, F.G.S.}

\author{
Borx Septemser 13, 1862. Died July 16, 1906.
}

As supplementary to the short notice given in our last number (p. 384), we may mention that Mr. Harris was born at Anglesey in Hampshire, and educated at Netherhampton House School, Wilton, near Salisbury. He subsequently attended classes at King's College, London, and the Birkbeck Institution. At an early age he became interested in geology and archrology, and he enlarged his knowledge during extensive travels in Europe and during visits paid to North Africa and the United States.

To the Geologioal Magazine he contributed papers on "The Gelinden Beds," 1887, p. 108; on "The Geology of Gironde," 1890, p. 22 ; and "A Juurney through Russia," 1898, pp. 9, 110.

In conjunction with Mr. H. W. Burrows, A.R.I.B.A., F.G.S., he publisherl a valuable account of "The Eocene and Oligocene Beds of the Paris Basin," with geological map and sections, and numerous lists of species and localities, pp. 1-129, 8vo (read before the Geologists' Association, April 3, 1891, and published separately, E. Stanford, price $3 s$.).

He added an Appendix to Mr. R. B. Newton's Systematic List of British Oligocene and Eocene Mollusca in the British Museum (1891), and prepared a catalogue of the Tertiary Mollusca of Australia $^{1}$ in the Geological Department (1897), 8vo, pp. 26 and 408 , with 8 plates, printed by order of the Trustees of the British Museum. In conjunction with Mr. Burrows be also named and arranged the Foreign Tertiary Mollusca in the Geological Department of the British Musenm.

Mr. Harris was for more than 20 years a regular contributor to the Builder, and wrote a series of articles upon "Building Stones," which were afterwards published separately. His attention thus became directed to questions of practical geology. He issued in 1888 a work entitled "Granites and our Granite Industries," and wrote on London Water Supply (1892); he contributed for

1 Intended to be one of a series. 
many years to the Clayworker, and published in 1897 a work on "The Science of Brickmaking." While largely engaged on economic questions he carried on investigations into the structure of oolitic freestones (1895), and found time likewise to write occasional papers on Eocene and Oligocene Mollusca in conjunction with his friend Mr. R. Bullen Newton.

\title{
RICHARD GLASCOTT SYMES, M.A.
}

\author{
Born MAY 8, 1840.
}

Digd JULY 27, 1906.

Son of Glascott Symes, M.D., a leading physician of Kingstown, in the county of Dublin, R. G. Symes was born in that town, graduated as Master of Arts and Licentiate of Engineering in Trinity College, Dublin, qualifying for the Mechanical Section of his degree at the Inchicore works of the Great Southern and Western Railway.

Having become interested in geology, he joined the Geological Survey of Ireland as Assistant Geologist under Jukes in 1863. In the course of his work he entirely surveyed six of the one-inch maps and portions of seventeen in conjunction with other members of the staff. Though his earliest work was carried out over forty years ago, his lines as then drawn remain unaltered, though some of the districts he completed, such as that of Lough Conn in Sheet 64, were of a very complicated nature. His latest Irish work was in county Antrim, which he was detailed to examine on account of his practical knowledge of the coal and iron deposits. It is especially satisfactory to note that recent exploration of the Ballycastle Cualfield has entirely justified the indications of his map and six-inch section. In 1869 Symes was promoted to the rank of Genlogist. In 1874 he was one of the Secretaries of Section C at the Meetiug of the British Association in Belfast, and in 1878 une of the Secretaries of Section G (Mechanical Science) at the Meeting in Dublin. His descriptive memoirs of the Irish areas he surveyed were interesting and clear, and his mapping and draughtsmanship of more than ordinary merit.

Upon the completion of the one-inch Geological Map of Ireland in 1890 he was transferred to the Scottish branch of the Survey, where he surveyed considerable portions of Kintyre and the neighbourhood of Oban in the Argyll district.

$\mathrm{H}_{\theta}$ was an ardent sportsman and keen observer of the fauna of the districts in which he was sncessively engaged, and there were few better practical authorities upon the birds and fishes of Ireland.

Injuries sustained by a car accident whilst engaged some years ago in surveying the country near Campbelton, N.B., shattered a previously robust frame. He retired from the public service in 1900, and settled in Moukstown, near Dublin, where he died on the 27 th of July, after a short illness.

R. C. 